\title{
Lauryl Gallate Induces Apoptotic Cell Death through Caspase- dependent Pathway in U87 Human Glioblastoma Cells In Vitro
}

\author{
CHIA-CHI LIU ${ }^{1,2}$, WEI-WEN LIN ${ }^{2,3}$, CHUN-CHI WU ${ }^{4,5}$, SHIH-LAN HSU 6 , \\ CHI-YEN WANG ${ }^{2}$, JING-GUNG CHUNG ${ }^{7,8^{*}}$ and CHI-SHIUN CHIANG ${ }^{1,9,10^{*}}$ \\ ${ }^{1}$ Department of Biochemical Engineering and Environmental Sciences, \\ National Tsing Hua University, Hsinchu, Taiwan, R.O.C.; \\ ${ }^{2}$ Cardiovascular Center, Taichung Veterans General Hospital, Taichung, Taiwan, R.O.C.; \\ ${ }^{3}$ Department of Life Science, Tunghai University, Taichung, Taiwan, R.O.C.; \\ ${ }^{4}$ Institute of Medicine, Chung Shan Medical University, Taichung, Taiwan, R.O.C.; \\ ${ }^{5}$ Department of Medical Research, Chung Shan Medical University Hospital, Taichung, Taiwan, R.O.C.; \\ ${ }^{6}$ Department of Education \& Research, Taichung Veterans General Hospital, Taichung, Taiwan, R.O.C.; \\ ${ }^{7}$ Department of Biological Science and Technology, China Medical University, Taichung, Taiwan, R.O.C.; \\ ${ }^{8}$ Department of Biotechnology, Asia University, Taichung, Taiwan, R.O.C.; \\ ${ }^{9}$ Institute of Nuclear Engineering and Science, National Tsing Hua University, Hsinchu, Taiwan, R.O.C.; \\ ${ }^{10}$ Frontier Research Center on Fundamental and Applied Sciences of Matters, \\ National Tsing Hua University, Hsinchu, Taiwan, R.O.C.
}

\begin{abstract}
Background/Aim: The treatment of human glioma tumor is still an unmet medical need. Natural products are always promising resources for discovery of anticancer drugs. Lauryl gallate $(L G)$ is one of the derivatives of gallic acid, widely present in plants, that has been shown to induce anticancer activities in many human cancer cell lines; however, it has not been studied in human glioma cell lines. Thus, the effects of LG on human glioblastoma U87 cells were investigated in the present in vitro study. Materials and Methods: Cell morphology and viability were examined by phase-contrast microscopy. Annexin V/Propidium iodide (PI) double staining were performed and assayed by flow cytometry to confirm that viable cell number reduction was
\end{abstract}

This article is freely accessible online.

*These Authors contributed equally to this work.

Correspondence to: Jing-Gung Chung, Ph.D., Department of Biological Science and Technology, China Medical University, No 91, Hsueh-Shih Road, Taichung 40402, Taiwan, R.O.C. Tel: +886 422053366 ext. 8000, Fax: +886 422053764, e-mail: jgchung@mail.cmu.edu.tw and ChiShiun Chiang, Department Biomedical Engineering and Environmental Sciences, National Tsing Hua University, No 101, Sec. 2, Kuang-Fu Road, Hsinchu 30013, Taiwan, R.O.C. Tel: +886 5733168, Fax: +886 5718639, e-mail: cschiang@mx.nthu.edu.tw

Key Words: Lauryl gallate, apoptotic cell death, caspase pathway, human glioblastoma U87 cells. due to the induction of apoptosis. Furthermore, U87 cells were exposed to $L G$ in various concentrations and were analyzed by caspase activity assay. To further confirm that $L G$ induced apoptotic cell death, the expression of apoptosisassociated proteins in LG-treated U87 cells was tested by western blot. Results: LG induced morphological changes and decreased viability in U87 cells. Annexin V/PI double staining revealed that $L G$ induced apoptotic cell death in U87 cells in a dose-dependent manner. The increased activities of caspase-2, $-3,-8$ and -9 demonstrated that $L G$ induced U87 cell apoptosis through a caspase-dependent pathway. In terms of molecular level, LG increased proapoptotic proteins Bax and Bak and decreased anti-apoptotic protein Bcl-2 in U87 cells. Furthermore, LG also suppressed the expression of $p$-Akt, Pak1, Hif- $1 \alpha$ and Hif- $2 \alpha, \beta$-catenin and Tcf-1 in U87 cells. Conclusion: These results suggest that $L G$ induced apoptotic cell death via the caspasedependent pathway in U87 cells.

Glioma is recognized as the most common primary tumor of the central nervous system, comprising about $50 \sim 60 \%$ of malignant brain tumors (1). Glioblastoma multiforme (GBM) is the most common and most malignant type of glioma in adults (2). Patients with GBM have a median survival time of 1 year, while $<5 \%$ of patients survive for 5 years, worldwide (3). Currently, the standard treatment of GBM includes surgery, radiation therapy, chemotherapy, or other adjuvant therapy or combinations of radiotherapy and chemotherapy or combined modalities (4-6). The median 
survival after brain tumor resection is 8-13 months. However, surgery with radiotherapy and chemotherapy provided significant benefit in median overall survival (21.3 months). Despite many advances in brain tumor therapy, the maximal benefit of treatment is limited and almost all patients relapse $(7,8)$. Thus, many investigators are focused on discovering new compounds for the treatment of GBM, particularly ingredients derived from natural products.

It is well accepted that compounds capable of inducing cancer cell death by apoptosis would be the best strategy for anticancer therapy. Apoptosis is a normal process of programmed cell death that includes a cascade of events leading to signal transduction (9), cell shrinkage and nuclei condensation $(10,11)$, and degradation of cellular protein and DNA (12). It is well documented that apoptosis is activated via two major routes, the death receptor or extrinsic pathway and the mitochondrial or intrinsic pathway; however, mitochondria play a critical role in the commitment of cells to apoptosis in both pathways (13). So far, many natural compounds have been identified to induce proapoptotic effects, and they could be considered as promising candidates for novel cancer therapeutics (14-16).

Lauryl gallate (LG) is a derivative of gallic acid, a natural plant triphenol. LG acts as an antioxidant via inhibiting xanthine oxidase and subsequently preventing the generation of superoxide radicals (17), as an anti-bacterial factor through inhibiting the growth of Gram-positive Bacillus subtilis (18), and also as anti-viral against African swine fever virus in Vero cells (19). It is noteworthy that LG has only limited toxicity to normal cells, and thus, it has been used as an antioxidant food additive since long (20). Previous in vivo studies have shown that LG not only prevents the formation of dimethylbenzanthracene-induced skin tumours, but also selectively kills tumor cells on established tumours in mice (21).

However, there is no report on the effect of LG in human brain tumor cells. Thus, in the present study, LG was investigated as a potential therapeutic agent for human brain tumor. In particular, the induction of cell apoptosis was examined in U87 human glioblastoma cells treated with LG in vitro. The results demonstrated that $\mathrm{LG}$ decreased the total viable cell number via the induction of apoptotic cell death through mitochondrial pathways and the activation of caspase-3.

\section{Materials and Methods}

Chemicals and reagents. LG, propidium iodide (PI), Tris- $\mathrm{HCl}$, trypsin, trypan blue and dimethyl sulfoxide (DMSO) were obtained from Sigma Chemical Co. (St. Louis, Missouri, USA). LG was dissolved in DMSO as a stock for further experiments. Dulbecco's modified Eagle's medium (DMEM; Gibco; Thermo Fisher Scientific, Inc., Waltham, MA, USA), fetal bovine serum (FBS) and penicillin-streptomycin were purchased from Invitrogen (Carlsbad, California, USA).
Cell culture. The U87 human glioblastoma cell line was obtained from the Food Industry Research and Development Institute (Hsinchu, Taiwan) and were cultured in DMEM medium supplemented with $10 \%$ FBS, $0.1 \mathrm{mg} / \mathrm{ml}$ streptomycin, and 100 $\mathrm{U} / \mathrm{ml}$ penicillin and were incubated at $37^{\circ} \mathrm{C}$ in a humidified atmosphere of $5 \% \mathrm{CO}_{2}(22)$.

Cell morphological changes and viability assay. U87 cells $\left(2 \times 10^{4}\right.$ cells/well) were maintained in 12-well plate for $24 \mathrm{~h}$ and were treated with $\mathrm{LG}(0,0.1,0.3,0.5 \mu \mathrm{M})$ for 24 and $48 \mathrm{~h}$. After treatment, cells morphological changes evaluated by photographed under contrastphase microscopy. Cells were harvested and were stained with PI (5 $\mu \mathrm{g} / \mathrm{ml}$ ) for cell viability by flow cytometry (Becton-Dickinson, San Jose, CA, USA) as previously described (23).

Apoptotic cell death assay. U87 cells $\left(2 \times 10^{4}\right.$ cells/well) were incubated with LG $(0,0.1,0.25,0.5$, and $1 \mu \mathrm{M}) 24 \mathrm{~h}$. Cells were harvested and were double stained with Annexin V/PI for total apoptotic cell death analysis by flow cytometry as previously described (24).

Measurement of caspase-2,-3,-8, -9 and -12 activities. U87 cells $\left(5 \times 10^{5}\right.$ cells $/ 100 \mathrm{~mm}$-dish $)$ were treated with $\mathrm{LG}(0,0.25,0.5,1 \mu \mathrm{M})$ for $48 \mathrm{~h}$. Cells were collected and resuspended in lysis buffer $(10 \mathrm{mM}$ Tris- $\mathrm{HCl} \mathrm{pH} \mathrm{7.4,} 150 \mathrm{mM} \mathrm{NaCl}$ and $1 \%$ Triton X-100). Cell lysate was used for measuring total protein by Bio-Rad protein assay kit (Bio-Rad, Hercules, CA, USA) with bovine serum albumin (BSA) as the standard. Cell lysates $(50 \mu \mathrm{g})$ were incubated at $37^{\circ} \mathrm{C}$ with substrates for each caspase, conjugated to the fluorescent reporter molecule 7-amino-4-trifluoromethyl coumarin (AFC) [Caspase-2 (VDVAD-AFC), Caspase-3 (DEVD-AFC), Caspase-8 (IETD-AFC), Caspase-9 (LEHD-AFC), and Caspase-12 (ATAD-AFC); R\&D Systems Minneapolis, MN, USA]. After incubation for $7 \mathrm{~h}$, cleavage of the peptide by caspase enzymatic activity released the fluorochrome (excitation/emission=405/510 nm). The level of caspase enzymatic activity was directly proportional to the fluorescence signal detected with a fluorescent microplate reader (Fluoroskan Ascent, Labsystems, Helsinki, Finland) as described previously (27).

Western blotting analysis. U87 cells $\left(5 \times 10^{5}\right.$ cells $/ 100 \mathrm{~mm}$-dish) were incubated with $L G$ at various final concentrations $(0,0.25,0.5$ and $1 \mu \mathrm{M})$ for $24 \mathrm{~h}$. Cells were harvested and gently resuspended in lysis buffer (10 mM Tris pH 7.5, 0.5 mM EDTA pH 8.0,0.5 mM DTT, $0.5 \%$ CHAPS, $10 \%$ glycerol) supplemented with a cocktail of protease inhibitors (Thermo Fisher Scientific) and were incubated for $30 \mathrm{~min}$ on ice. Cell debris were removed by centrifugation at $10,000 \mathrm{~g}$ at $4^{\circ} \mathrm{C}$ for $20 \mathrm{~min}$. All supernatants were used for measuring total protein by Bio-Rad protein assay kit (Bio-Rad, Hercules, CA, USA) with bovine serum albumin (BSA) as the standard. About $30 \mu \mathrm{g}$ of each sample were separated by SDS polyacrylamide gel electrophoresis and then electrotransferred onto a PVDF membrane (Millipore, Bedford, MA, USA). The membrane was washed and incubated with blocking buffer (5\% BSA, 1X Tris buffered saline, $0.1 \%$ Tween 20 ) for $1 \mathrm{~h}$ followed by incubation with primary antibodies against BAX, B-cell lymphoma 2 (BCL2), Bcl-2 antagonist/killer protein (BAK), $\beta$-actin, T-cell factor-1 (Tcf-1), Tcf3, Tcf-4, lymphoid enhancer-binding factor 1 (LEF-1) (Santa Cruz Biotechnology, Santa Cruz, CA, USA), hypoxia-inducible factor $1 \alpha$ (HIF-1 $\alpha$ ), HIF-2 $\alpha$, phosphorylated AKT serine/threonine kinase (pAKT), phosphorylated $\mathrm{p} 21$-activated kinase-1 (p-PAK-1) and $\beta$ Catenin (Cell Signaling, Danvers, MA, USA). After washed, the membranes were incubated with HRP-conjugated anti-rabbit IgG 

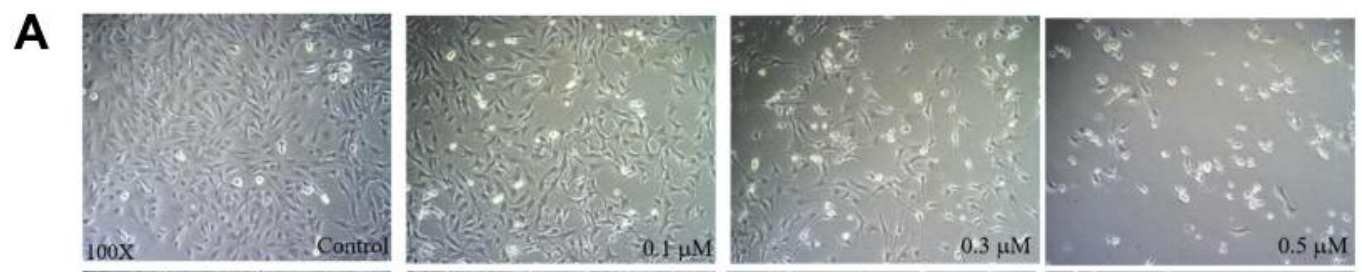

$24 \mathrm{~h}$
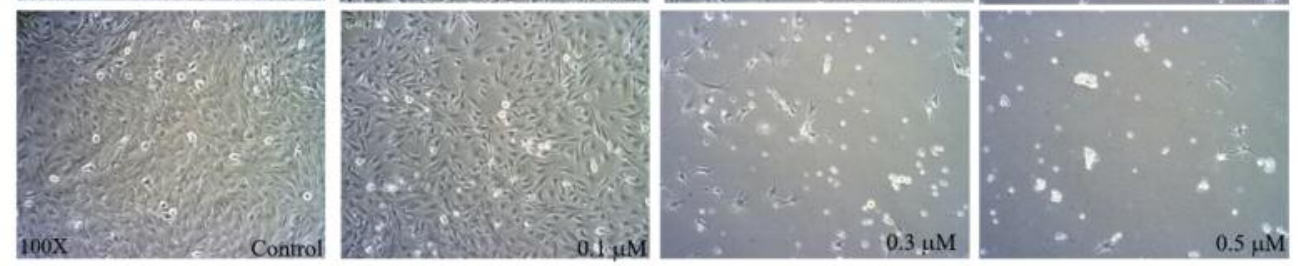

$48 \mathrm{~h}$

B

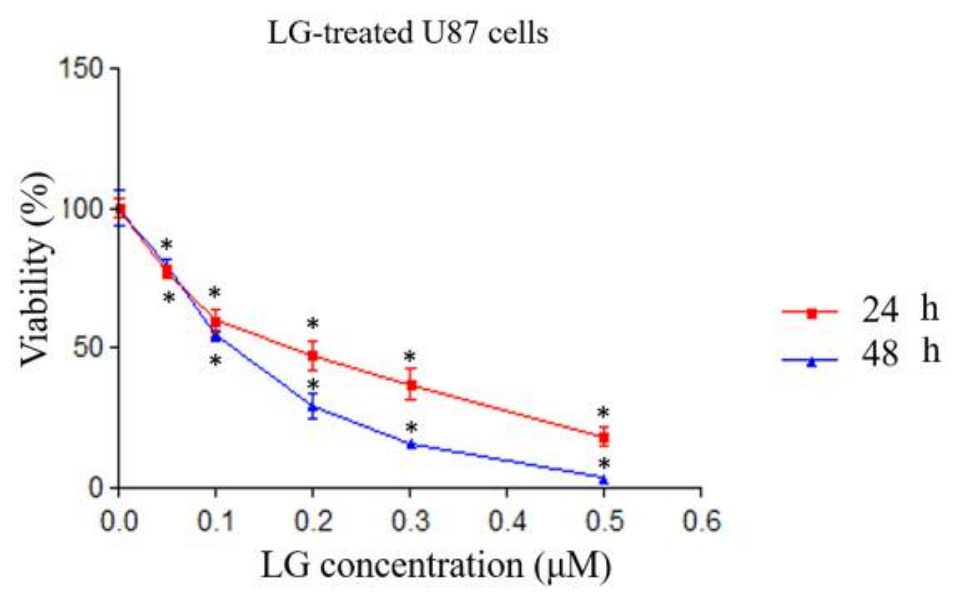

Figure 1. Lauryl gallate $(L G)$ induced cell morphological changes and decreased cell viability in U87 cells. U87 cells were treated with LG $(0$, $0.05,0.1,0.2,0.3,0.5 \mu \mathrm{M})$ for 24 and $48 \mathrm{~h}$. A: Cell morphological changes were examined and photographed at 24 and 48 h. B: Total cell viability was measured. ${ }^{*} p<0.05$, significant difference between LG-treated groups and the control as analyzed by Student's t test.

secondary antibody $(1: 10,000)$ (Cell Signaling). Immunoreactive protein was visualized and detected by ImmobilonTM Western Chemiluminescent HRP Substrate (Millipore, Billerica, MA, USA) $(23,24)$. ImageJ software (National Institutes of Health, Bethesda, MD, USA) was used for band density quantification.

Immunocytochemistry. U87 cells were fixed with $4 \%$ paraformaldehyde in PBS and washed twice with cold PBS. The fixed cells were permeabilized and blocked with $0.1 \%$ Triton X-100 and $1 \%$ BSA simultaneously for $1 \mathrm{~h}$. Cells were then incubated for $1 \mathrm{~h}$ with anti- $\beta$-catenin antibody (Cell Signaling) diluted in PBS containing $1 \%$ BSA. After incubation with FITC-conjugated secondary antibody (Cell Signaling, MA, USA) at room temperature for $1 \mathrm{~h}$, cells were stained with DAPI (Thermo Fisher Scientific) and mounted over glass slides. Protein expression of b-catenin was evaluated using a confocal laser scanning microscope (Olympus FV1000, Tokyo, Japan).

Statistical analysis. The results were expressed as mean \pm standard deviation (SD). Figures are representative one of three independent experiments. Statistical analysis was performed by Student's $t$-test with statistical significance of $p<0.05$.

\section{Results}

LG induced cell morphological changes and decreased cell viability in U87 cells. U87 cells treated with LG were examined for morphological changes at 24 and $48 \mathrm{~h}$. Results indicated that LG induced cell morphological changes at both treated times based on cell debris and shrinking (Figure 1A). Cell viability was also analyzed, and results showed decreased total viable cell number of U87 cells in a dosedependent manner (Figure $1 \mathrm{~B}$ ). The $\mathrm{IC}_{50}$ value of LG in U87 cells was about $0.2 \mu \mathrm{M}$ for $24 \mathrm{~h}$ treatment.

$L G$ induced apoptotic cell death in U87 cells. To examine how LG induced U87 cell death, U87 cells were treated with LG $(0,0.1,0.25,0.5$ and $1 \mu \mathrm{M})$ for $24 \mathrm{~h}$ and then examined by Annexin V/PI double staining followed by flow cytometry. The results indicated that $\mathrm{LG}$ induced earlier and late apoptotic cell death (Figure 2A). Furthermore, LG induced apoptotic cell death in U87 cells in a dose-dependent manner 

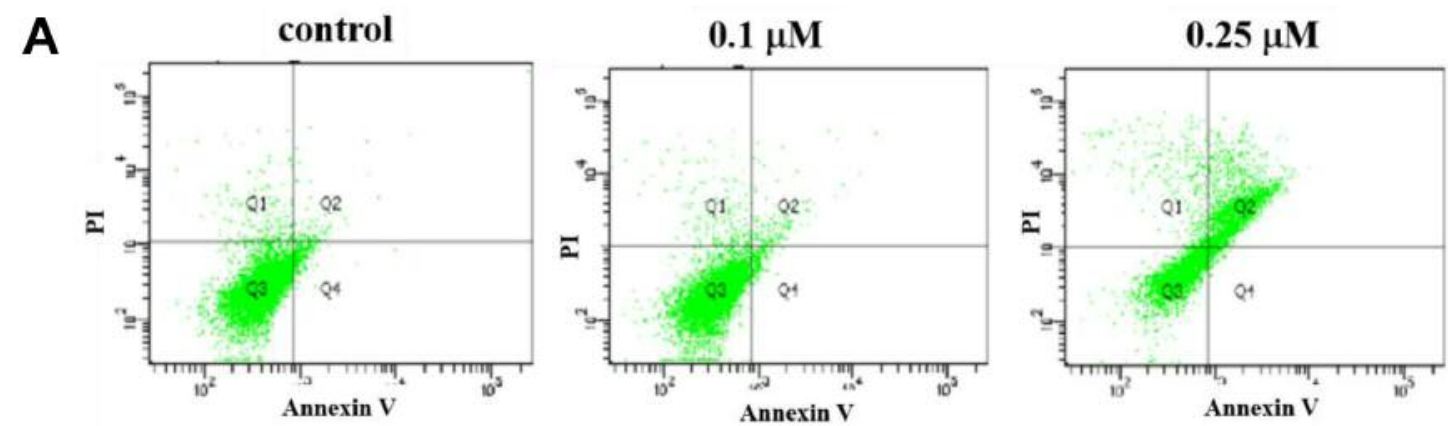

$0.5 \mu \mathbf{M}$
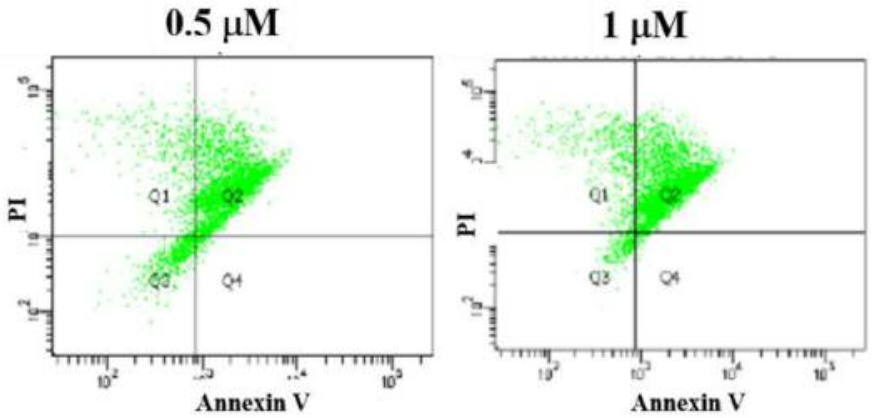

B

LG-treated U87 cells

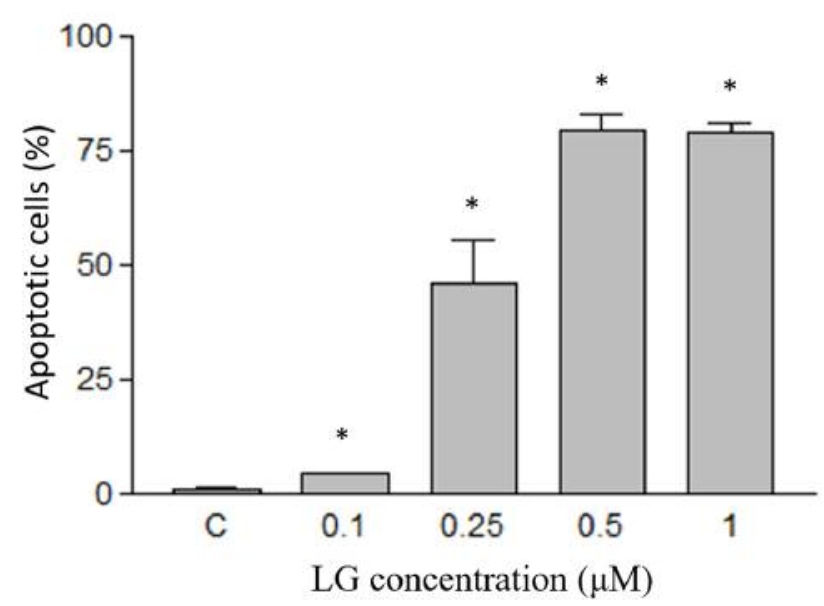

Figure 2. Lauryl gallate (LG) induced apoptotic cell death in U87 cells. U87 cells were treated with LG $(0,0.05,0.1,0.2,0.25,0.3,0.5$ and 1.0 $\mu M)$ for $24 \mathrm{~h}$ and apoptotic cell death was determined by Annexin V/PI double staining and analyzed by flow cytometry assay. A: representative profiles; B: calculated percentage of apoptotic cell death. ${ }^{*} p<0.05$, significant difference between LG-treated groups and the control as analyzed by the Student's t test.

(Figure 2B). As shown in Figure 2, percentage of Annexin V/PI double positive U87 cells were $1.3 \pm 0.4 \%, 4.6 \pm 0.2 \%$, $46.1 \pm 16.3 \%, 79.5 \pm 5.9 \%$ and $78.9 \pm 4.0 \%$ after a $24-\mathrm{h}$ treatment with $0,0.1,0.25,0.5$ and $1 \mu \mathrm{M} L G$, respectively, indicating that LG induced apoptosis in U87 cells.

$L G$ affected the enzymatic activity of Caspase-2, -3, -8, -9 and -12 in U87 cells. To further investigate the involvement of caspases in LG-induced apoptosis, U87 cells were treated with $\mathrm{LG}(0,0.1,0.25$, and $1 \mu \mathrm{M})$ for $48 \mathrm{~h}$ and the activities of caspase-2, $-3,-8,9$ and -12 were evaluated for $7 \mathrm{~h}$. Results indicated that LG significantly promoted the activities of caspase-2, $-3,-8$ and -9 (LG-induced caspase activity: caspase-3>-9>-2>-8) in a dose-dependent manner, but not the activity of caspase-12. Treatment of U87 cells with various concentrations of LG for $48 \mathrm{~h}$ resulted in significant increases in the activities of caspase-2, $-3,-8$, and -9 (Figure 3 and Table I). 
Enzymatic activity of Caspases

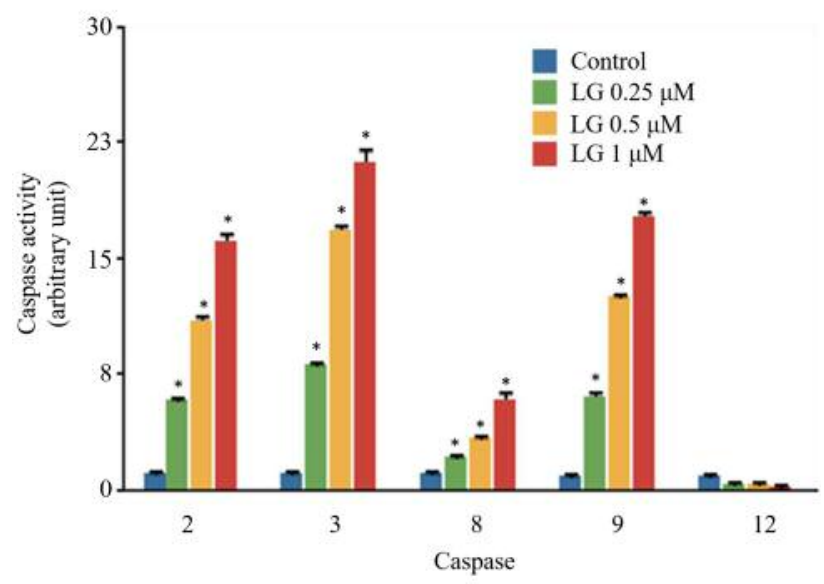

Figure 3. Lauryl gallate (LG) affects caspase-2, -3, -8, -9 and -12 activities in U87 cells. U87 cells treated with LG $(0,0.1,0.25$, and $1 \mu \mathrm{M})$ for $48 \mathrm{~h}$, and the activities of caspase-2, -3, -8, 9 and -12 were measured. $* p<0.05$, significant difference between LG-treated groups and the control as analyzed by Student's t test.

$L G$ altered apoptosis-associated protein expression in U87 cells. To further confirm the molecular mechanisms of LGinduced apoptotic cell death in U87 cells, the expression of apoptosis-associated proteins was examined in LG-treated cells. Results indicated that LG significantly increased proapoptotic protein expression of BAX and BAK, while decreased the expression of anti-apoptotic protein BCL-2 (Figure 4A). Furthermore, we found that cells treated with LG (only at $1 \mu \mathrm{M}$ ) had significantly decreased expression of HIF$1 \alpha$ and $-2 \alpha$, p-AKT and PAK-1, which are associated with cell survival (Figure 4B). In addition, this study also showed that LG decreased the expression of $\beta$-Catenin, TCF-1, TCF-3, TCF-4 and LEF-1 in U87 cells (Figure 4C). The quantitative results of protein expression under LG exposure in U87 cells are shown in Figure 4 D. The expression of $\beta$-Catenin in U87 cells was further examined by confocal laser microscopy systems after exposed to $\mathrm{LG}(0,0.25,0.5$ and $1 \mu \mathrm{M})$ for $24 \mathrm{~h}$. Results confirmed that LG decreased the expression of $\beta$ catenin in U87 cells and this effect was dose-dependent (Figure 5).

\section{Discussion}

LG has been shown to have antitumor activities in vitro and in vivo $(21,26)$ and exert its cytotoxic effects through the induction of apoptotic cell death in many human cancer cell lines $(21,26-27)$. However, there is no available evidence on LG apoptotic effects on glioma cells in vitro. In the present study, we used U87 human glioblastoma cells to demonstrate the potential of LG as an anti-cancer agent in vitro.
Table I. The quantitative results (mean $\pm S D$, arbitrary units) of caspase activity in U87 cells after LG treatment.

\begin{tabular}{lccrr}
\hline & Control & LG $0.25 \mu \mathrm{M}$ & LG $0.5 \mu \mathrm{M}$ & LG $1 \mu \mathrm{M}$ \\
\hline Caspase-2 & $1.1 \pm 0.1$ & $5.9 \pm 0.1^{*}$ & $11.0 \pm 0.7^{*}$ & $16.1 \pm 0.9^{*}$ \\
Caspase-3 & $1.2 \pm 0.2$ & $8.2 \pm 0.4^{*}$ & $16.7 \pm 0.7^{*}$ & $21.2 \pm 1.6^{*}$ \\
Caspase-8 & $1.1 \pm 0.1$ & $2.2 \pm 0.1^{*}$ & $3.4 \pm 0.1^{*}$ & $5.8 \pm 1.0^{*}$ \\
Caspase-9 & $1.0 \pm 0.0$ & $6.0 \pm 0.8^{*}$ & $12.6 \pm 0.5^{*}$ & $17.7 \pm 0.7^{*}$ \\
Caspase-12 & $0.9 \pm 0.1$ & $0.4 \pm 0.0$ & $0.4 \pm 0.0$ & $0.3 \pm 0.0$ \\
\hline
\end{tabular}

${ }^{*} p<0.05$, significant difference between LG-treated groups and the control as analyzed by the Student's $t$-test.

Initially, the cytotoxic effects of LG on U87 cells were examined and LG was found to induce cell morphological changes and decrease the total viable cell number in a dosedependent manner. In order to investigate whether the LGinduced U87 cell death was due to apoptosis or not, Annexin V/PI double staining, which has generally been used to measure apoptosis of cancer cells (28), was performed. Results indicated that LG reduced the total cell number via the induction of apoptotic cell death in U87 cells. These effects were also dose-dependent. Based on our evidence and the literature that suggests the induction of cancer cell apoptosis as a promising strategy for anticancer therapy (2932 ), LG is a promising candidate as an anticancer drug for glioma.

It is well known that cancer cell apoptosis can be induced through caspase- dependent and -independent pathways (33, 34). Thus, in order to investigate whether LG induced apoptosis in U87 cells via the activation of caspases, the enzymatic activities of caspases $-2,-3,-8,-9$ and 12 were measured. It was demonstrated that LG increased the activities of all caspases, except casaspe-12, suggesting that LG-induced cell apoptosis in U87 cells is mediated through caspasedependent pathways. It has previously been shown that the metabolite of cholesterol, pregnenolone, induced caspasedependent apoptosis in glioma cells in vitro, involving Fas-Fas ligand interaction, followed by the activation of caspase- 8 and -9 at $24 \mathrm{~h}$, and caspase- $3 / 7$ at $48 \mathrm{~h}$ (35). The pregnenoloneinduced intrinsic apoptosis may be through disruption of lipid rafts (35). Although LG does not share similar structure with pregnenolone, it might influence the properties of lipid rafts followed by induction of intrinsic apoptosis because of its amphipathic structure. However, further investigations should be performed to demonstrate the mechanism.

Moreover, the expression of pro-apoptotic and antiapoptotic proteins in LG-treated U87 cells was analyzed. It is known that the BCL-2 family proteins are involved in mitochondrial membrane permeability, which is important for the induction of the intrinsic apoptotic pathway, and they can 

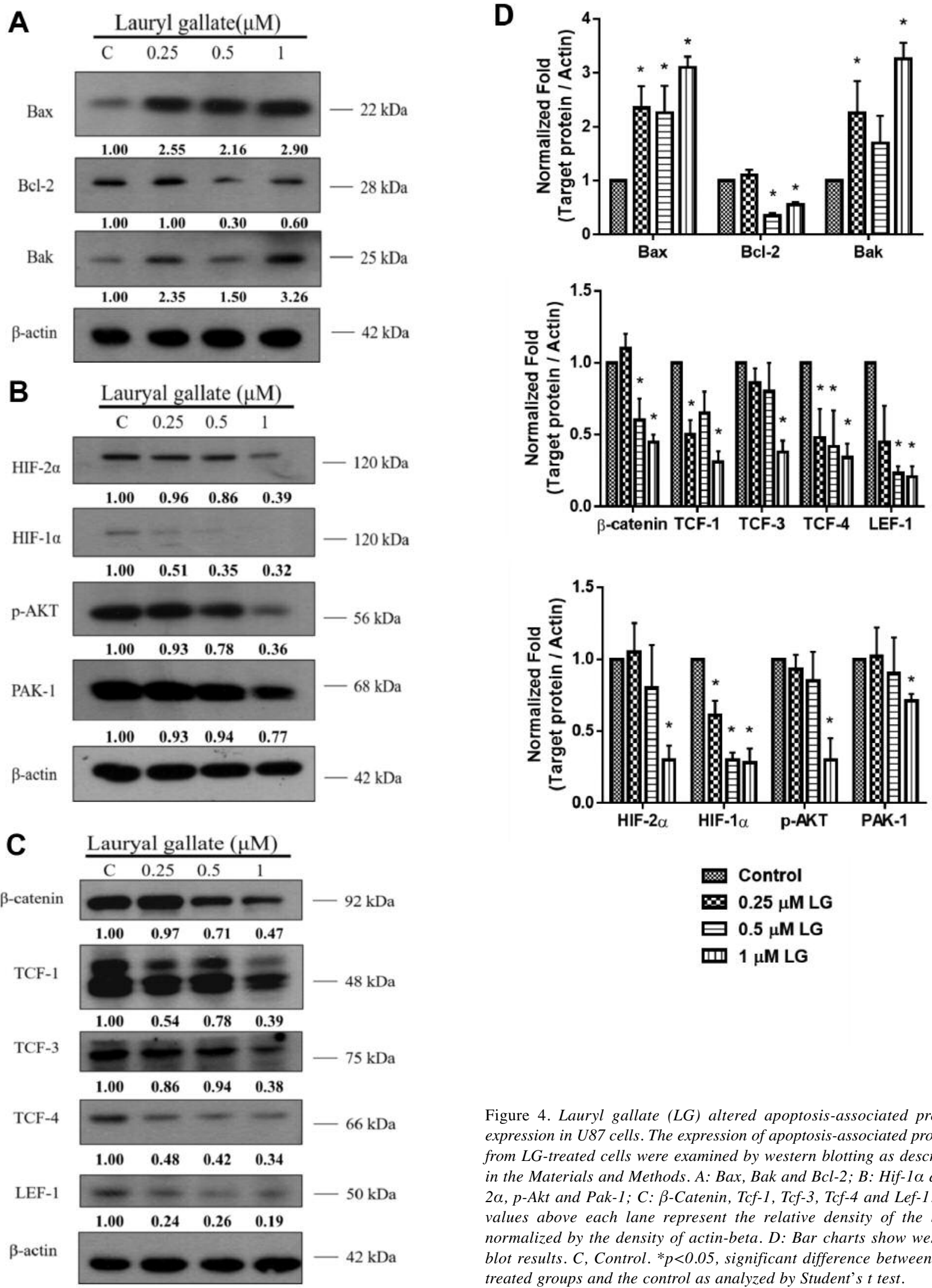

Figure 4. Lauryl gallate ( $L G)$ altered apoptosis-associated protein expression in U87 cells. The expression of apoptosis-associated proteins from LG-treated cells were examined by western blotting as described in the Materials and Methods. A: Bax, Bak and Bcl-2; B: Hif-1 $\alpha$ and $2 \alpha, p$-Akt and Pak-1; C: $\beta$-Catenin, Tcf-1, Tcf-3, Tcf-4 and Lef-1. The values above each lane represent the relative density of the band normalized by the density of actin-beta. D: Bar charts show western blot results. $C$, Control. ${ }^{*} p<0.05$, significant difference between $L G$ treated groups and the control as analyzed by Student's t test. 


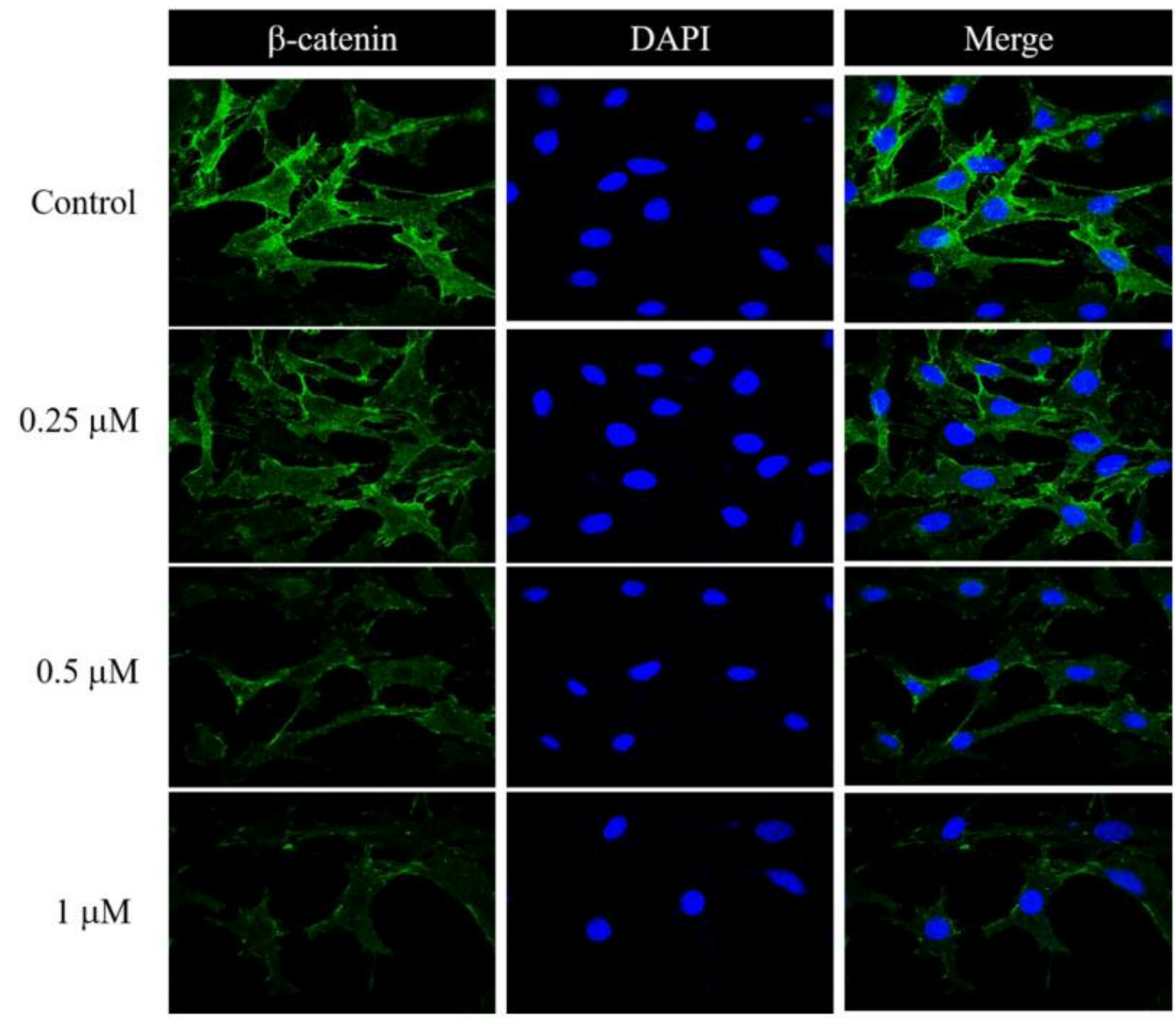

Figure 5. Lauryl gallate $(L G)$ suppressed the expression of $\beta$-catenin in U87 cells. U87 cells treated with 0,0.25, 0.5 and $1 \mu M$ for $24 \mathrm{~h}$ were examined for the expression of $\beta$-catenin. After incubation, cells were collected for staining with anti- $\beta$-catenin antibody and were examined and photographed by confocal laser microscopy systems.

be classified into pro-apoptotic $(\mathrm{BAX})$ and anti-apoptotic (BCL-2) proteins $(36,37)$. Western blot showed that LG increased the expression of pro-apoptotic proteins BAX and BAK (Figure 4A) and suppressed the level of anti-apoptotic protein such as BCL-2 (Figure 4A) in U87 cells. These results suggested that LG-induced apoptosis of U87 might be through the intrinsic pathway. Furthermore, it has been reported that increased $\mathrm{BAX} / \mathrm{BCL}-2$ ratio can affect the mitochondrial membrane potential leading to apoptosis via caspasedependent and/or caspase-independent pathways (38). It has also been documented that the BAX/BCL-2 ratio affects cellfate determination, and might be involved in the formation of various apoptosis-related diseases, as well $(39,40)$. Thus, the increase of BAX/BCL-2 ratio induced by LG in U87 cells might alter their mitochondrial membrane potential.

The present results also showed that LG decreased the protein levels of HIF- $1 \alpha$ and $-2 \alpha$, p-AKT and PAK-1 in U87 cells (Figure 4B). HIF-1 $\alpha$ is a transcription factor and a critical regulator for cellular oxygen balance, since it is also involved in cellular survival during hypoxia (41). Numerous studies have shown that HIF-1 $\alpha$ inhibition induces apoptosis in many cancer cell lines, including glioblastoma $(42,43)$. Furthermore, previous studies have reported that downregulation of MCL-1 and HIF- $1 \alpha$ is implicated in curcumin-mediated apoptosis in infantile hemangioma endothelial cells (44). AKT is also involved in cell survival $(45,46)$; It is activated by phosphorylation (47) and, herein, it was shown that LG inhibited the expression of p-AKT (Figure 4B). Inhibition of AKT phosphorylation may increase susceptibility of cells to apoptosis, which has been previously reported in pancreatic beta-cells (48).

The present results also showed that LG suppressed the expression of PAK1 in U87 cells in a dose-dependent manner. Previous studies on melanoma and gastric cancer have reported that PAK-targeted therapeutics might have anti-tumor effects $(49,50)$. Currently, many investigators are 
focused on identifying selective PAK inhibitors for specific tumors (51). Moreover, previous studies have demonstrated that TCF-1 has higher expression in some cancer cells and suppression of $\beta$-Catenin signaling has been shown to suppress the pancreatic tumor growth by disrupting nuclear $\beta$-Catenin/TCF-1 complex (52). Herein, it was demonstrated that the expression of $\beta$-Catenin and TCF- $1,-3$ and -4 and LEF-1 was decreased in LG-treated U87 cells. We also used confocal laser microscopy systems to examine the $\beta$-Catenin expression of LG-treated cells and results confirmed that LG suppressed the expression of $\beta$-Catenin in U87 cells, in a dose-dependent manner (Figure 5).

To our knowledge, this is the first study to show that LG induces apoptotic cell death in U87 glioblastoma cells in vitro. The effects of LG were mediated via caspasedependent pathways, as shown by increased expression of pro-apoptotic proteins and decreased expression of antiapoptotic BCL-2. Thus, our results suggest that LG is a promising candidate for anti-tumor therapy for GMB.

\section{Acknowledgements}

This work was supported by the grants -MOST 106-2627-M-001001 (C. S. Chiang) and TCVGH-1053102A (C. C. Liu).

\section{References}

1 Brandes, AA, Tosoni A, Franceschi E, Reni M, Gatta G and Vecht C: Glioblastoma in adults. Crit Rev Oncol Hematol 67: 139-152, 2008.

2 Bonavia R, Inda MM, Cavenee WK and Furnari FB: Heterogeneity maintenance in glioblastoma: a social network. Cancer Res 71: 4055-4060, 2011.

3 Hou LC, Veeravagu A, Hsu AR and Tse VC: Recurrent glioblastoma multiforme: a review of natural history and management options. Neurosurg Focus 20: E5, 2006.

4 Furnari FB, Fenton T, Bachoo RM, Mukasa A, Stommel JM, Stegh A, Hahn WC, Ligon KL, Louis DN, Brennan C, Chin L, DePinho RA and Cavenee WK: Malignant astrocytic glioma: genetics, biology, and paths to treatment. Genes Dev 21: 26832710, 2007.

5 Sabbagh AJ and Alaqeel AM: Focal brainstem gliomas. Advances in intra-operative management. Neurosciences (Riyadh) 20: 98-106, 2015.

6 Zhao B, Bian EB, Li J and Li J: New advances of microRNAs in glioma stem cells, with special emphasis on aberrant methylation of microRNAs. J Cell Physiol 229: 1141-1147, 2014.

7 Anton K, Baehring JM and Mayer T: Glioblastoma multiforme: overview of current treatment and future perspectives. Hematol Oncol Clin North Am 26: 825-853, 2012.

8 de Groot JF and Mandel JJ: Update on anti-angiogenic treatment for malignant gliomas. Curr Oncol Rep 16: 380, 2014.

9 Ashkenazi A and Dixit VM: Death receptors: signaling and modulation. Science 281: 1305-1308, 1998.

10 Orlov SN, Dam TV, Tremblay J and Hamet P: Apoptosis in vascular smooth muscle cells: role of cell shrinkage. Biochem Biophys Res Commun 221: 708-715, 1996.
11 Shimizu T, Maeno E and Okada Y: Prerequisite role of persistent cell shrinkage in apoptosis of human epithelial cells. Sheng $\mathrm{Li}$ Xue Bao 59: 512-516, 2007.

12 Thornberry NA and Lazebnik Y: Caspases: enemies within. Science 281: 1312-1316, 1998.

13 Takahashi A, Masuda A, Sun M, Centonze VE and Herman B: Oxidative stress-induced apoptosis is associated with alterations in mitochondrial caspase activity and Bcl-2-dependent alterations in mitochondrial pH (pHm). Brain Res Bull 62: 497-504, 2004.

14 Chan KT, Meng FY, Li Q, Ho CY, Lam TS, To Y, Lee WH, Li $\mathrm{M}, \mathrm{Chu} \mathrm{KH}$ and Toh M: Cucurbitacin B induces apoptosis and $\mathrm{S}$ phase cell cycle arrest in BEL-7402 human hepatocellular carcinoma cells and is effective via oral administration. Cancer Lett 294: 118-124, 2010.

15 Gong $\mathrm{K}$ and Li W: Shikonin, a Chinese plant-derived naphthoquinone, induces apoptosis in hepatocellular carcinoma cells through reactive oxygen species: A potential new treatment for hepatocellular carcinoma. Free Radic Biol Med 51: 22592271, 2011.

16 Yang XR, Wang YY, La KK, Peng L, Song XH, Shi XG, Zhu XF, Leung PC, Ko CH and Ye CX: Inhibitory effects of cocoa tea (Camellia ptilophylla) in human hepatocellular carcinoma HepG2 in vitro and in vivo through apoptosis. J Nutr Biochem 23: 10511057, 2012.

17 Kubo I, Masuoka N, Xiao P and Haraguchi H: Antioxidant activity of dodecyl gallate. J Agric Food Chem 50: 3533-3539, 2002.

18 Kubo I, Fujita K, Nihei K and Nihei A: Antibacterial activity of akyl gallates against Bacillus subtilis. J Agric Food Chem 52: 1072-1076, 2004.

19 Hurtado C, Bustos MJ, Sabina P, Nogal ML, Granja AG, Gonzalez ME, Gonzalez-Porque P, Revilla Y and Carrascosa AL: Antiviral activity of lauryl gallate against animal viruses. Antivir Ther 13: 909-917, 2008.

20 van der Heijden CA, Janssen PJ and Strik JJ: Toxicology of gallates: a review and evaluation. Food Chem Toxicol 24: 1067-1070, 1986.

21 Ortega E, Sadaba MC, Ortiz AI, Cespon C, Rocamora A, Escolano JM, Roy G, Villar LM and Gonzalez-Porque P: Tumoricidal activity of lauryl gallate towards chemically induced skin tumours in mice. Br J Cancer 88: 940-943, 2003.

22 Wang Z, Liu Z, Yu G, Nie X, Jia W, Liu RE and Xu R: Paeoniflorin inhibits migration and invasion of human glioblastoma cells via suppression transforming growth factor beta-induced epithelial-mesenchymal transition. Neurochem Res 43: 760-774, 2018.

23 Zhang X, Yashiro M, Qiu H, Nishii T, Matsuzaki T and Hirakawa $\mathrm{K}$ : Establishment and characterization of multidrug-resistant gastric cancer cell lines. Anticancer Res 30: 915-921, 2010.

24 Liu KC, Huang YT, Wu PP, Ji BC, Yang JS, Yang JL, Chiu TH, Chueh FS and Chung JG: The roles of AIF and Endo G in the apoptotic effects of benzyl isothiocyanate on DU 145 human prostate cancer cells via the mitochondrial signaling pathway. Int J Oncol 38: 787-796, 2011.

25 Teng CL, Han SM, Wu WC, Hsueh CM, Tsai JR, Hwang WL and Hsu SL: Mechanistic aspects of lauryl gallate-induced differentiation and apoptosis in human acute myeloid leukemia cells. Food Chem Toxicol 71: 197-206, 2014.

26 Serrano A, Palacios C, Roy G, Cespon C, Villar ML, Nocito M and Gonzalez-Porque P: Derivatives of gallic acid induce apoptosis in tumoral cell lines and inhibit lymphocyte proliferation. Arch Biochem Biophys 350: 49-54, 1998. 
27 Roy G, Lombardia M, Palacios C, Serrano A, Cespon C, Ortega E, Eiras P, Lujan S, Revilla Y and Gonzalez-Porque P: Mechanistic aspects of the induction of apoptosis by lauryl gallate in the murine B-cell lymphoma line Wehi 231. Arch Biochem Biophys 383: 206$214,2000$.

28 Liu KC, Shih TY, Kuo CL, Ma YS, Yang JL, Wu PP, Huang YP, Lai KC and Chung JG: Sulforaphane induces cell death through $\mathrm{G}_{2} / \mathrm{M}$ phase arrest and triggers apoptosis in HCT 116 human colon cancer cells. Am J Chin Med 44: 1289-1310, 2016.

29 Chou WH, Liu KL, Shih YL, Chuang YY, Chou J, Lu HF, Jair HW, Lee MZ, Au MK and Chung JG: Ouabain Induces Apoptotic Cell Death Through Caspase- and Mitochondriadependent Pathways in Human Osteosarcoma U-2 OS Cells Anticancer Res 38: 169-178, 2018.

30 Sarosiek KA, Ni Chonghaile T and Letai A: Mitochondria: gatekeepers of response to chemotherapy. Trends Cell Biol 23: 612-619, 2013.

31 Verheij M, Vens C and van Triest B: Novel therapeutics in combination with radiotherapy to improve cancer treatment: rationale, mechanisms of action and clinical perspective. Drug Resist Updat 13: 29-43, 2010

32 Yang Y, Zhang Y, Wang L and Lee S: Levistolide A induces apoptosis via ROS-mediated ER stress pathway in colon cancer cells. Cell Physiol Biochem 42: 929-938, 2017.

33 Khazaei S, Abdul Hamid R, Ramachandran V, Mohd Esa N, Pandurangan AK, Danazadeh F and Ismail P: Cytotoxicity and Proapoptotic Effects of Allium atroviolaceum Flower Extract by Modulating Cell Cycle Arrest and Caspase-Dependent and p53Independent Pathway in Breast Cancer Cell Lines. Evid Based Complement Alternat Med 2017: 1468957, 2017.

34 Lin CH, Chan HS, Tsay HS, Funayama S, Kuo CL and Chung JG: Ethyl acetate fraction from methanol extraction of Vitis thunbergii var. taiwaniana induced $\mathrm{G}_{0} / \mathrm{G}_{1}$ phase arrest via inhibition of cyclins $\mathrm{D}$ and $\mathrm{E}$ and induction of apoptosis through caspase-dependent and -independent pathways in human prostate carcinoma DU145 cells. Environ Toxicol 33: 41-51, 2018.

35 Xiao X, Chen L, Ouyang Y, Zhu W, Qiu P, Su X, Dou Y, Tang L, Yan M, Zhang H, Yang X, Xu D and Yan G: Pregnenolone, a cholesterol metabolite, induces glioma cell apoptosis via activating extrinsic and intrinsic apoptotic pathways. Oncol Lett 8: 645-650, 2014

36 Adams JM and Cory S: The Bcl-2 apoptotic switch in cancer development and therapy. Oncogene 26: 1324-1337, 2007.

37 Cory S and Adams JM: The Bcl2 family: regulators of the cellular life-or-death switch. Nat Rev Cancer 2: 647-656, 2002.

$38 \mathrm{Su}$ ZY, Tung YC, Hwang LS and Sheen LY: Blazeispirol A from Agaricus blazei fermentation product induces cell death in human hepatoma Hep 3B cells through caspase-dependent and caspase-independent pathways. J Agric Food Chem 59: 51095116,2011

39 Yip KW and Reed JC: Bcl-2 family proteins and cancer. Oncogene 27: 6398-6406, 2008.

40 Youle RJ and Strasser A: The BCL-2 protein family: opposing activities that mediate cell death. Nat Rev Mol Cell Biol 9: 47$59,2008$.
41 Semenza GL: Hypoxia-inducible factor 1: master regulator of $\mathrm{O}_{2}$ homeostasis. Curr Opin Genet Dev 8: 588-594, 1998.

42 Vordermark D: In regard to DAI et al: inhibition of hypoxia inducible factor 1alpha causes oxygen-independent cytotoxicity and induces p53 independent apoptosis in glioblastoma cells. IJROBP 2003;55:1027-1036). Int J Radiat Oncol Biol Phys 57: 1196, 2003.

43 Erler JT, Cawthorne CJ, Williams KJ, Koritzinsky M, Wouters BG, Wilson C, Miller C, Demonacos C, Stratford IJ and Dive C: Hypoxia-mediated down-regulation of Bid and Bax in tumors occurs via hypoxia-inducible factor 1-dependent and -independent mechanisms and contributes to drug resistance. Mol Cell Biol 24: 2875-2889, 2004

44 Lou S, Wang Y, Yu Z, Guan K and Kan Q: Curcumin induces apoptosis and inhibits proliferation in infantile hemangioma endothelial cells via downregulation of MCL-1 and HIF-1alpha. Medicine (Baltimore) 97: e9562, 2018.

45 Janku F: Phosphoinositide 3-kinase (PI3K) pathway inhibitors in solid tumors: From laboratory to patients. Cancer Treat Rev 59: 93-101, 2017.

46 Lee CC, Lin ML, Meng M and Chen SS: Galangin Induces p53independent $\mathrm{S}$-phase arrest and apoptosis in human nasopharyngeal carcinoma cells through inhibiting PI3K-AKT signaling pathway. Anticancer Res 38: 1377-1389, 2018.

47 Elghazi L and Bernal-Mizrachi E: Akt and PTEN: beta-cell mass and pancreas plasticity. Trends Endocrinol Metab 20: 243-251, 2009.

48 Kapodistria K, Tsilibary EP, Politis P, Moustardas P, Charonis A and Kitsiou P: Nephrin, a transmembrane protein, is involved in pancreatic beta-cell survival signaling. Mol Cell Endocrinol 400: 112-128, 2015.

49 Chuang YC, Wu HY, Lin YL, Tzou SC, Chuang CH, Jian TY, Chen PR, Chang YC, Lin CH, Huang TH, Wang CC, Chan YL and Liao KW: Blockade of ITGA2 induced apoptosis and inhibits cell migration in gastric cancer. Biol Proced Online 20: 10, eCollection, 2018.

50 Araiza-Olivera D, Feng Y, Semenova G, Prudnikova TY, Rhodes $\mathrm{J}$ and Chernoff J: Suppression of RAC1-driven malignant melanoma by group A PAK inhibitors. Oncogene 37: 944-952, 2018.

51 Dummler B, Ohshiro K, Kumar R and Field J: Pak protein kinases and their role in cancer. Cancer Metastasis Rev 28: 5163, 2009.

52 Pramanik KC, Fofaria NM, Gupta P, Ranjan A, Kim SH and Srivastava SK: Inhibition of beta-catenin signaling suppresses pancreatic tumor growth by disrupting nuclear beta-catenin/TCF1 complex: critical role of STAT-3. Oncotarget 6: 11561-11574, 2015. 